\title{
PSOL versus PSOL: facções, partidos e mídias digitais
}

Marcelo Alves dos Santos Junior ${ }^{1}$

Afonso de Albuquerque ${ }^{2}$ (i)

\begin{abstract}
Este artigo investiga os desafios que as mídias sociais apresentam em relação ao poder das cúpulas dos partidos de definir o discurso majoritário. A hipótese é de que, em contexto de fragmentação partidária, as mídias sociais oferecem oportunidades para correntes internas vocalizarem insatisfações e negociarem suas agendas publicamente, o que gera ruídos externos e dificulta consensos. 0 estudo de caso focaliza as disputas travadas entre diferentes facções do PSOL acerca da aliança com PT, PCdoB e Rede na eleição para a prefeitura do Rio de Janeiro em 2016. Coletamos dados a partir de requisições à Graph API para mapear a presença de lideranças, diretórios, facções e núcleos dos quatro partidos. Os achados indicam a distância estrutural entre os subsistemas comunicativos organizados em torno do PSOL e do PT-PCdoB e a ríspida discussão pública sobre a composição da aliança eleitoral.

Palavras-chave: mídias sociais, partido; PSOL; esquerda; Facebook
\end{abstract}

\section{Introdução}

Entre abril e junho de 2016, lideranças do PSOL, do PCdoB e da Rede negociaram uma possível aliança para o lançamento de candidatura única à prefeitura do Rio de Janeiro. Os três pré-candidatos representantes do espectro ideológico esquerdista, Alessandro Molon (Rede), Jandira Feghali (PCdoB) e Marcelo Freixo (PSOL), chegaram a se reunir com o propósito de evitar a divisão dos votos e garantir uma alternativa unificada às candidaturas da chapa incumbente, liderada por Pedro Paulo (PMDB), e da oposição conservadora, de Marcelo Crivella (PRB), que acabou sendo eleito no segundo turno. $O$ esforço ganhava relevância em face das circunstâncias políticas que se apresentavam naquele momento. Por um lado, o cenário político nacional favorecia a união de amplos setores da esquerda em torno da luta contra o impeachment da presidente Dilma Rousseff, que eles, bem como diversos analistas políticos (Albuquerque, 2019; Santos e Guarnieri, 2016), qualificaram como um golpe. Por outro lado, o papel de destaque que o PMDB

\footnotetext{
1 Universidade Federal Fluminense. Superintendência de Comunicação Social. Niterói (RJ), Brasil. E-mail: $<$ marcelo_alves@id.uff.br>.

2 Universidade Federal Fluminense. Departamento de Estudos Culturais e Mídia. Niterói (RJ), Brasil. E-mail: <afonsoal@uol.com.br>
} 
desempenhou nesse processo inviabilizou a continuidade da aliança entre esse partido, 0 PT e o PCdoB em nível local, e incentivou esses dois últimos partidos a buscar uma aproximação com outras forças de esquerda no estado.

Contudo, as negociações pela chapa única foram mal recebidas por setores do PSOL, liderados pela facção Corrente Socialista dos Trabalhadores (CST). Em resposta, a CST publicou o "Manifesto pela Frente Socialista de Esquerda nas eleições do Rio de Janeiro em 2016". O manifesto também circulou nas mídias sociais, por meio da criação de uma página no Facebook intitulada "Pela Frente Socialista de Esquerda nas eleições do Rio", divulgando textos e imagens dos encontros contra a aliança com PT, PCdoB e Rede. Após um mês de debates e ferozes contendas nas mídias sociais, gerando disputas externas entre as lideranças dos partidos da esquerda carioca e internas entre facções do PSOL, a proposta fracassou. Ao final, três partidos envolvidos na tentativa de coordenação eleitoral lançaram candidatura própria.

O episódio chama a atenção para questões que têm sido pouco exploradas pela literatura acadêmica: a importância do papel que as facções desempenham nas dinâmicas partidárias e as oportunidades que as mídias digitais oferecem a esse respeito. $\mathrm{Na}$ conjuntura contemporânea, há uma popularização e uma personalização do consumo de informação política pelas mídias sociais em virtude da interação individualizada com as lideranças, que criam bases de seguidores mais volumosas que as organizações partidárias (Braga, Rocha e Carlomagno, 2015). Em linhas gerais, os estudos de comunicação política sobre os partidos operam em dois extremos, ou muito além ou muito aquém do âmbito em que as facções se tornam um fenômeno analiticamente significativo. O primeiro grupo toma a unidade dos partidos como um dado não problemático e supõe que os meios de comunicação reproduzem os pontos de vista do partido como um todo. Estudos desse tipo inicialmente investigaram o uso da televisão como instrumento de comunicação partidária (Dias, 2013) e, mais recentemente, passaram a explorar as oportunidades oferecidas pelas mídias digitais a esse respeito, seja no modelo mais tradicional dos websites dos partidos (Gibson e Ward, 2000; Gibson e Rommele, 2001; Norris, 2003; Braga, França e Nicolás, 2009), seja no uso que estes fazem de mídias sociais como Twitter e Facebook (Enli e Skogerbø, 2013). No extremo oposto, estão os estudos que dão conta do potencial dos meios de comunicação (e, particularmente, das mídias digitais) no sentido de viabilizar um empoderamento dos indivíduos no interior dos partidos e servir como instrumento de "equalização" (Gibson e Ward, 2009) e democratização das dinâmicas intrapartidárias (Jackson e Lilleker, 2009), e aqueles focados no potencial que as mídias sociais oferecem para a construção de novos modelos de mobilização política, alternativos aos partidos, como a ação conectiva proposta por Bennett e Segerberg (2012).

Tendo em vista as disputas travadas entre diferentes facções do PSOL acerca da aliança com PT, PCdoB e Rede na eleição para a prefeitura do Rio de Janeiro em 2016, este artigo se propõe a discutir os desafios que as mídias sociais apresentam do ponto de vista das relações intrapartidárias e, em particular, da capacidade das cúpulas dos partidos de 
definir o discurso majoritário e as estratégias de comunicação política a serem adotadas em campanhas eleitorais e em outras ocasiões de relevância estratégica. Em conformidade com a abordagem organizacional da comunicação partidária, estudos demonstraram que as ferramentas digitais jogam luz sobre disputas internas em partidos faccionalizados e oferecem oportunidades para correntes internas tangenciarem as elites partidárias, obterem visibilidade nas mídias e ganharem força para negociar suas agendas (Ceron, 2017). Dessa forma, a internet contribui decisivamente para a multiplicação de espaços de comunicação de órgãos e representantes partidários e, consequentemente, para a desunião no discurso.

O PSOL oferece um exemplo particularmente interessante a esse respeito, dado que seu modelo de organização reconhece e legitima a existência de facções (ou "tendências"), e é, dentre os partidos existentes no país, um dos que têm empregado mais intensivamente as mídias sociais como recurso de comunicação política. Esse artigo se dedica ao estudo de caso acerca das disputas discursivas de facções internas do PSOL que ganharam visibilidade no Facebook com um posicionamento contra o acordo realizado pelas lideranças do partido com PT, Rede e PCdoB para organização das estratégias eleitorais e unificação da chapa. Para isso, realizamos um mapeamento não somente das páginas dos partidos municipais, mas também das lideranças locais envolvidas em negociações, diretórios regionais e, principalmente, facções. O estudo combinou métodos de análise de redes sociais para identificar as redes de conexão intra e interpartidárias e análise de conteúdo dos posicionamentos contidos em 44 postagens para aferir de quais atores partiram as controvérsias e os ruídos contra a unificação da chapa.

O artigo está organizado da seguinte forma: A primeira seção, "Equalização ou normalização? A internet e a democratização da comunicação partidária", revisa a literatura acadêmica sobre internet e política e, de modo especial, uma tradição de investigação sobre a influência potencial exercida pelo uso das tecnologias da informação e comunicação no tocante às relações que se estabelecem no interior das organizações partidárias, uma tradição investigativa que já conta com 25 anos de desenvolvimento. A segunda seção, "Comunicação digital e organização partidária", apresenta a abordagem organizacional dos partidos políticos e como os estudos das facções pode contribuir para lançar outros olhares sobre a comunicação digital. A terceira seção, "Partidos e esquerda no Rio - Conjuntura histórica", contextualiza a disputa político-eleitoral das prévias de 2016 no Rio de Janeiro e o papel do PT na estruturação do campo da esquerda. Em "Metodologia, problema e hipóteses", são detalhados o desenho de pesquisa e os procedimentos de coleta de dados e de análise de redes sociais no Facebook. A quarta seção, "Resultados e análise", apresenta os principais resultados, mostrando, com base na análise das ligações entre 54 fanpages associadas ao PSOL, entre as quais 14 vinculadas a facções do partido, e 135 fanpages de outros três partidos da esquerda (PT, PCdoB e Rede), as controvérsias entre as lideranças e as principais facções do PSOL em torno da candidatura do partido e a coordenação estratégica com outros partidos de esquerda para 
a eleição municipal. Nas "Conclusões", retomamos os principais argumentos e apontamos caminhos para pesquisas futuras no campo da comunicação partidária na internet.

\section{Equalização ou normalização? A internet e a democratização da comunicação partidária}

Nas duas últimas décadas, a pesquisa sobre o uso das ferramentas digitais pelos partidos políticos e seu impacto se tornou um campo de investigação consolidado. Em linhas gerais, a literatura acadêmica sobre o tema tem explorado duas ordens de questões relativas ao potencial da internet para: 1) fomentar a participação dos indivíduos nas atividades dos partidos, aumentando a sua democracia interna; e 2) reduzir a assimetria de poder e de visibilidade entre os partidos por meio de um canal de comunicação direta com os públicos. Esta seção apresenta os principais argumentos associados a essas duas perspectivas, tendo em vista seus avanços e limitações, para, em seguida, sugerir a necessidade de explorar uma via analítica alternativa, que considere a questão sob um prisma organizacional.

Desde o princípio, a pesquisa sobre a relação entre partidos políticos e internet tem sido dominada por uma questão fundamental: em que medida a internet providenciaria condições para uma transformação da política como um todo e do papel dos partidos nessa transformação em particular. Um primeiro conjunto de trabalhos centrou o seu foco no problema da interação entre partidos e indivíduos. Norris (2003), por exemplo, destacou o potencial dos websites dos partidos políticos para incrementar a participação dos cidadãos comuns na vida partidária. Para a autora, não obstante o objetivo principal desses websites seja o de garantir uma comunicação de cima para baixo, de modo a informar, persuadir e mobilizar apoio de militantes e simpatizantes, eles abririam a possibilidade de uma comunicação no sentido inverso, permitindo aos cidadãos comuns oportunidades para prover algum retorno e influenciar nos debates internos sobre as propostas dos partidos. Outros, como Strommer-Galley (2000) e Coleman (2005), vão mais longe e sugerem que a internet pode ser um fator favorável ao incremento do processo conversacional e deliberativo no interior dos partidos. Esses estudos compartilham a expectativa de que o uso desse recurso comunicativo possa abrir espaços para trocas discursivas e consultas sobre políticas que empoderem os indivíduos, possibilitando maior controle sobre as decisões da elite burocrática dos partidos. Essa perspectiva se sustenta na dimensão participativa da democracia e na affordance interativa da tecnologia, na qual o partido é uma variável passiva, submetido ao questionamento de cumprir ou não o ideal de responsividade.

Estudos organizacionais, porém, matizaram consideravelmente as expectativas participativas, sugerindo que atores políticos evitam a interação nos espaços digitais, preferindo investir na disseminação de informações (Vaccari, 2008; Jackson e Lilleker, 2009; Braga, França e Nicolás, 2009; Blanchard, 2016) ou numa "interação controlada" 
em plataformas de mobilização eleitoral pela distribuição de atividades gerenciadas e moderadas pela direção da campanha (Strommer-Galley, 2014). Essa interação controlada teria o objetivo de evitar a perda do controle sobre a mensagem, o risco à imagem e a exposição a críticas de oponentes. Em particular, Lilleker, Pack e Jackson (2010) sugeriram que, visto que uma das finalidades dos partidos é ganhar e manter o poder, os líderes se questionam se a interatividade online traria, de fato, algum benefício político, como vencer eleições, angariar recursos e mobilizar apoio na sociedade. Tais perspectivas normativas, dessa forma, foram entendidas como um recurso discursivo desvinculado das instâncias de tomada de decisão.

A segunda abordagem diz respeito ao debate sobre a capacidade da internet para nivelar a visibilidade e a influência política entre partidos majoritários e minoritários. A literatura se divide em dois argumentos concorrentes: (1) equalização: as ferramentas digitais possuem características especiais que mitigam a assimetria de poder e de visibilidade, levando, em última análise, à igualdade da competição partidária (Gibson e Ward, 2009); e (2) normalização: as ferramentas digitais possuem influência residual para alterar as disputas interpartidárias, na medida em que organizações com mais recursos e membros têm maior eficiência em se apropriar do meio e reproduzir as desigualdades políticas (Margolis, Resnick e Tu, 1997; Vaccari, 2008). Estudos empíricos encontraram evidências que sustentam ambos os argumentos, combinando traços que apontam para normalização e equalização (Norris, 2003). No entanto, autores argumentam que a discussão entre as duas escolas não faz avançar o conhecimento em relação às condicionantes institucionais para o uso da internet (Anstead e Chadwick, 2008). O problema é que a dicotomia normalização/equalização pouco contribui para entender os processos políticos e comunicativos concretos e o contexto dos sistemas políticos em que os partidos se inserem.

Não obstante a considerável influência que essas perspectivas exerceram na pesquisa sobre o uso da internet pelos partidos políticos, elas apresentam algumas limitações. A expectativa de que a internet teria um potencial para incrementar a qualidade da participação política, confirmada ou negada por essas investigações, não se originou do nada, mas, como observou Mosco (2004), tem a sua gênese em uma mitologia política bastante específica, patrocinada por agentes como o think tank Progress and Freedom Foundation (PFF), que atribuía ao ciberespaço o potencial de promover uma sociedade mais horizontal e focada antes nos interesses e necessidades dos cidadãos individuais que nas instituições políticas, vistas como corruptas e antidemocráticas. Como resultado disso, os estudos frequentemente tomam a comunicação digital de forma abstrata, desconectada do partido enquanto organização burocrática com fins políticos específicos (Rommele, 2003). Os sites são investigados como unidades que gravitam num vácuo, pois não são considerados o ambiente da comunicação política digital e as relações dos partidos e seus componentes com outros atores políticos (Albuquerque e Martins, 2010). 


\section{Comunicação digital e organização partidária}

A análise dos partidos políticos sob uma perspectiva organizacional tem uma sólida tradição no âmbito da ciência política que remete, dentre muitos exemplos, à proposição da "lei de ferro da oligarquia", de Robert Michels (1954), à distinção entre modelos de organização centralizados e descentralizados, de Maurice Duverger (1970), e ao destaque que Panebianco (2005) dispensa aos dilemas organizativos, exigências contraditórias que afetam os partidos políticos tanto quanto quaisquer outras organizações complexas. Contudo, o impacto dessa perspectiva na pesquisa da comunicação partidária digital tem sido, até o presente, bastante limitado.

Partidos são compostos por diversos subgrupos com objetivos, recursos e métodos de atuação particulares. Panebianco subdivide esses segmentos em facções (mais organizados) e tendências (menos organizados). "Num partido cujos grupos internos são facções (grupos de elevada organização), o controle sobre as zonas de incerteza é disperso (subdividido entre as facções) e a coalizão dominante é pouco coesa" (Panebianco, 2005, p. 75). Além de considerar diversos tipos de facções, devemos pontuar como elas idealmente se comportam em partidos que possuem dinâmicas e objetivos diferentes. Wolinetz (2002) sugere a distinção em três categorias: (a) policy-seeking: fortemente orientado pela defesa de agendas e programas políticos; (b) vote-seeking: abre mão de políticas programáticas em busca de maximizar seu capital eleitoral; e (c) office-seeking: tem como principal característica a barganha por cargos no governo e em estatais. Esperase que os partidos reorientem suas estratégias de comunicação política de acordo com essas características e com suas finalidades específicas. Dependendo do nível de organização e institucionalização das facções, elas podem vocalizar publicamente sua insatisfação com decisões internas e aumentar o preço das barganhas (Maor, 1995; Polk e Kolln, 2017).

Em linhas gerais, a abordagem organizacional da comunicação partidária em meios digitais fundamenta-se nos diferentes usos das novas tecnologias da comunicação (NTCs) pelos partidos, de acordo com os objetivos e tipologias organizacionais. Rommelle (2003) argumenta que os contextos políticos condicionam a apropriação dessas ferramentas. A autora mitiga o tecnodeterminismo, na medida em que "a adaptação não pode ser entendida como um modelo único. Embasando-me na literatura dos objetivos partidários e das tipologias partidárias clássicas, argumento que as NTCs desempenharão papéis diferentes em partidos diferentes" (Rommelle, 2003, p. 8).

Em vez de destacar as potencialidades interativas das novas ferramentas para renovar a qualidade da democracia e reaproximar os partidos dos eleitores, essa abordagem se concentra no modo como os partidos utilizam as ferramentas da internet para atingir seus objetivos organizacionais. Um dos aspectos fundamentais a se considerar aqui é que os partidos não são unidades coesas, sem tendências ou conflitos internos. Por esse motivo, a comunicação partidária não deve ser entendida meramente como expressão 
de uma perspectiva "oficial", unívoca, dos partidos políticos, mas se constitui também como espaço de conflito e negociação dos diferentes pontos de vista e interesses que se apresentam no interior das legendas.

Naturalmente, os problemas que se apresentam à comunicação partidária variam amplamente de acordo com os recursos comunicacionais que se encontram à disposição. No Brasil, o modelo de propaganda política no rádio e na televisão transforma os partidos políticos no vetor central das campanhas eleitorais, ao conceder a eles tempo gratuito para a veiculação de suas mensagens políticas, tanto no bloco de propaganda política exibido em horários determinados (Horário Gratuito de Propaganda Eleitoral, ou HGPE) quanto nas inserções exibidas nos intervalos comerciais (spots políticos).

O HGPE e os spots políticos se constituem como uma dinâmica institucional de distribuição de incentivos coletivos e seletivos (Panebianco, 2005) através da comunicação partidária. O primeiro caso diz respeito ao esforço de projeção da imagem partidária (Dias, 2005) nos programas de rádio e televisão. O segundo exemplo se refere à distribuição desigual de tempo entre os candidatos do partido, proporcionando a eles maior ou menor visibilidade pública (Cervi, 2011). De acordo com Schmitt, Carneiro e Kuschnir (1999), a distribuição desigual do tempo entre os candidatos em eleições proporcionais se configura como uma "lista partidária" informal, na medida em que ela impacta na competitividade de cada um deles no certame eleitoral. Por outro lado, autores argumentam que a distribuição do tempo no HGPE não obedece apenas a uma racionalidade eleitoral, mas se constitui como um meio para negociar/consolidar a distribuição de poder entre diferentes lideranças ou facções do partido (Albuquerque, Steibel e Carneiro, 2008).

O uso da internet como recurso de comunicação política oferece um novo conjunto de desafios e oportunidades para os partidos políticos. Um primeiro ponto a se considerar aqui - um ponto que a literatura sobre partidos e internet tem prestado relativamente pouca atenção - é que o termo geral "internet" comporta uma série de plataformas com naturezas e lógicas de funcionamento totalmente distintas entre si. Tradicionalmente, a pesquisa no campo privilegiou os websites como objeto de investigação (Gibson e Ward, 2000; Norris, 2003; Braga, França e Nicolás, 2009), o que faz sentido quando se considera que essa plataforma se desenvolveu anteriormente às demais como veículo de comunicação política. Não obstante os websites apresentem possibilidades comunicativas inteiramente diferentes daquelas dos meios de comunicação tradicionais (impressos, rádio e televisão), no que diz respeito ao barateamento do acesso à mídia - o que foi suficientemente demonstrado pela literatura sobre o potencial democratizante da internet que discutimos acima -, eles ainda propiciam um grau considerável de concentração do poder de falar pelo partido, uma vez que se trata de um espaço oficial de manifestação do partido e que pode prescindir de aspectos interativos, como caixas de comentários.

Por outro lado, as mídias sociais apresentam um desafio totalmente distinto, uma vez que, nelas, agentes oficiais, como os partidos, dividem espaço com todo o tipo de atores, de natureza coletiva ou individual. Tais características levam a que as mídias sociais 
sejam um ambiente particularmente desafiador para as lideranças que dominam os postos principais na hierarquia partidária, visto que outros agentes têm potencial de visibilidade. Esse processo tem consequências particularmente intensas em partidos com alto grau de facciosismo. Nesses espaços, a literatura vem demonstrando que a cúpula tem menos controle sobre a comunicação, e as disputas entre facções internas ganham exposição pública, contribuindo para fragmentar o discurso partidário e gerar crises com influência externa, como enfraquecimento das estratégias político-eleitorais de articulação com outros partidos (Ceron, 2017).

A bibliografia especializada recente possui alguns trabalhos com estudos empíricos sobre a comunicação de facções partidárias nas mídias sociais. Nesse sentido, Ceron (2017) analisa as mensagens dos perfis no Twitter para encontrar padrões de heterogeneidade intrapartidária. Ele mostra que a comunicação digital dá pistas importantes sobre as preferências ideológicas dos políticos, como a tendência de manifestar apoio em períodos eleitorais ou o descumprimento do encaminhamento da votação pela liderança partidária no parlamento. "Facebook e Twitter representam uma nova oportunidade para obter informações acerca do grau de heterogeneidade entre as visões políticas de facções partidárias ou políticos individuais e podem ser usados para responder a uma série de questões sobre dinâmicas intrapartidárias" (Ceron, 2017, p. 1). Todavia, inexiste na bibliografia nacional uma pesquisa que analise teórica ou empiricamente as consequências das mídias sociais para as instâncias de democracia partidária interna e atuação de facções para criar ruídos e enfraquecer as negociações interpartidárias.

\section{Partidos e esquerda no Rio - Conjuntura histórica}

Para que se possa entender a dinâmica das negociações de uma chapa única unindo PSOL, PCdoB e Rede, com o apoio do PT, na eleição municipal do Rio de Janeiro em 2016, é preciso ter em mente as características da conjuntura política de então. Quatro elementos se fazem particularmente importantes aqui. $O$ primeiro deles aponta para o enfraquecimento do PMDB, partido que permaneceu à frente do governo do estado do Rio de Janeiro desde 2003 e que, entre 2009 e 2016, controlou também a prefeitura da sua capital, através de Eduardo Paes. A liderança do PMDB no estado e no município do Rio de Janeiro foi muito favorecida pelas boas relações que o governador Sérgio Cabral (20062014) e o prefeito Eduardo Paes (2009-2016) mantiveram com o governo federal petista. Essas relações, contudo, pioraram dramaticamente depois da reeleição de Dilma Rousseff, em 2014, visto que lideranças peemedebistas tiveram um papel relevante no processo que culminou na sua deposição, em 2016, através de um golpe parlamentar, e sua sucessão pelo vice-presidente Michel Temer (PMDB-RJ). A despeito do sucesso obtido pelo partido em termos nacionais, o PMDB do Rio foi fortemente atingido pelas investigações de corrupção que serviram de pano de fundo para a deposição da presidente Dilma Rousseff, 
que levaram à prisão o ex-governador Sérgio Cabral e o ex-presidente da Câmara dos Deputados Eduardo Cunha. Por conta de todos esses fatores, o candidato escolhido para a sucessão de Eduardo Paes - seu secretário de governo Pedro Paulo - jamais foi capaz de se demonstrar competitivo, e viu sua situação política piorar ainda mais em função das denúncias de que ele teria agredido sua esposa - o que se tornou um tema permanente da campanha.

Tomados em conjunto, a queda do governo petista, em âmbito nacional, e a crise do PMDB no estado e no município do Rio de Janeiro abriram caminho para um segundo fator da conjuntura política: o surgimento de quatro candidaturas com perfil à direita, que demonstravam algum fôlego nas pesquisas de opinião: o senador Marcelo Crivella (PRB) liderava todos os cenários, com mais de $30 \%$ e uma plataforma clientelista; e três pleiteantes flutuavam em torno de 10\%: Carlos Osório (PSDB), ex-secretário de Transportes; Flávio Bolsonaro (PSC), defendendo um discurso de fortalecimento da segurança pública e combate à esquerda; e Índio da Costa (PSD), com plataforma voltada para a tecnologia e contra a corrupção.

O terceiro elemento que deve ser considerado diz respeito à fragmentação da esquerda no estado do Rio de Janeiro e, em particular, na sua capital. O PT do Rio de Janeiro enfrentou uma dificuldade histórica em lançar candidaturas próprias, visto que o estado muitas vezes serviu de moeda de troca com outras legendas para a construção de alianças em nível nacional (Dos Santos e Travagin, 2015). De acordo com essa lógica, o PT e o PCdoB do Rio de Janeiro apoiaram formalmente desde 2009 o governo de Eduardo Paes (PMDB) na cidade do Rio de Janeiro, recebendo a vice-prefeitura e cargos em secretarias. A manutenção dessa política se tornou inviável com o golpe parlamentar, e, em consequência, o PT retirou apoio ao pré-candidato do PMDB, Pedro Paulo, e formalizou aliança com o PCdoB para lançar Jandira Feghali³.

Historicamente, o PT serviu como baliza institucional e simbólica para o campo da esquerda no Brasil (Hunter, 2010), caracterizado por uma articulação de facções com tendências ideológicas bastante diferentes entre si (Leal, 2005; Amaral, 2010). Partidos como PSTU, PSOL e Rede se originaram de grupos ou quadros anteriormente filiados ao $\mathrm{PT}^{4}$, e os candidatos Marcelo Freixo (PSOL) e Alessandro Molon (Rede) militaram no partido, respectivamente, até 2005 e 2015. A saída de Molon, especialmente, foi consequência das críticas quanto à ligação entre PT e PMDB na capital (ele já havia sido

\footnotetext{
3 Disponível em: <http://extra.globo.com/noticias/extra-extra/pcdob-devolve-cargos-eduardo-paes-lancacandidatura-de-jandira-19127629.html>. Acesso em: 12 out. 2019.

${ }^{4}$ Apesar de as principais lideranças da Rede não terem saído diretamente do PT, como PSTU e PSOL, ou ocupado um lugar marcadamente de esquerda no espectro ideológico, podemos compreender a trajetória destas como um movimento de afastamento em relação ao PT, como é o caso de Marina Silva e Alessandro Molon. Essa chave de análise é fundamental para elucidar o processo de decisão das chapas únicas e o racha das esquerdas no pleito municipal de 2016 no Rio de Janeiro.
} 
preterido como candidato do partido em 2008, quando o PT apoiou Eduardo Paes) e de sua vontade de lançar candidatura própria a prefeito em $2016^{5}$.

O caso do PSOL merece uma atenção especial dado o foco do artigo. O partido foi fundado a partir de desfiliações de facções do PT, resultantes principalmente de disputas sobre votações no Congresso Nacional (Morais, 2014). Parlamentares como Luciana Genro, João Batista Oliveira de Araújo (Babá) e Heloísa Helena foram expulsos do PT por terem se posicionado contra a reforma da previdência. Genro e Babá também levaram os membros de suas facções trotskistas: o Movimento Esquerda Socialista (MES) e a Corrente Socialista dos Trabalhadores (CST). Além disso, o PSOL também recebeu tendências do PSTU, como o Coletivo Socialismo e Liberdade (C-SOL), que deixou o PSTU em desacordo com a proibição de facções internas. Freixo deixou o PT em 2005 e se elegeu deputado estadual pelo PSOL em 2006.

Assim, o PSOL nasceu como alternativa ao PT, defendendo um posicionamento de esquerda socialista, diferenciando-se do discurso catch all petista. O momento de sua fundação marca a organização partidária como uma legenda composta por diversas facções internas e decisão concentrada nos congressos, diretórios e convenções: "as ações e formulações do partido se iniciam em sua base, em seus órgãos mais básicos que são os Núcleos e as Setoriais, embora, ainda, as decisões sejam tomadas nas instâncias decisórias" (Morais, 2014, p. 18).

Em linhas gerais, esse quadro dá conta das razões que levaram ao esforço de unir as candidaturas de Marcelo Freixo, Jandira Feghali e Alessandro Molon em uma estratégia comum para a eleição, e os empecilhos que ela enfrentou. Em particular, a proposta gerou insatisfação entre as correntes periféricas do PSOL. As facções Corrente Socialista dos Trabalhadores (CST) e Liberdade, Socialismo e Revolução (LSR) lançaram o "Manifesto pela Frente Socialista de Esquerda no Rio de Janeiro" em seus sites a nas mídias sociais, fazendo campanha contra a possível chapa única. Em plenária, a proposta do bloco amplo de esquerda foi derrotada. No dia 4 de julho, o PSOL oficializou a pré-candidatura de Marcelo Freixo à prefeitura do Rio de Janeiro, em chapa composta somente pelo PCB, colocando ponto final à estratégia de união da esquerda. No primeiro turno da eleição, Freixo ficou em segundo lugar, com 18,3\% dos votos, o que o habilitou a disputar o segundo turno com Marcelo Crivella, que obteve cerca de $27,8 \%$ dos votos. Jandira e Molon tiveram, respectivamente, $3,3 \%$ e $1,4 \%$ dos votos. No segundo turno, Crivella superou Freixo com $59,4 \%$ dos votos, contra $40,6 \%$.

\section{Metodologia, problema e hipóteses}

Este artigo se propõe a discutir os desafios que as mídias sociais apresentam do ponto de vista das relações intrapartidárias e, em particular, da capacidade das cúpulas

\footnotetext{
${ }^{5}$ Disponível em: <http://odia.ig.com.br/noticia/rio-de-janeiro/2015-09-24/molon-anuncia-saida-do-pt-emdocumento-de-tres-paragrafos.html>. Acesso em: 12 out. 2019.
} 
dos partidos de definir o discurso majoritário e as estratégias de comunicação política a serem adotadas em campanhas eleitorais e em outras ocasiões de relevância estratégica. O problema fundamental é que as ferramentas digitais, e principalmente as mídias sociais, expõem publicamente as controvérsias de partidos faccionalizados e oferecem oportunidades para correntes internas tangenciarem as elites partidárias, gerar ruído no processo de decisão interno e mobilizar suas bases para negociar suas agendas (Ceron, 2017). Dessa forma, as mídias sociais contribuem decisivamente para a multiplicação de espaços de comunicação de órgãos e representantes partidários e, consequentemente, para a articulação de campanhas públicas contrárias às decisões majoritárias do partido.

Questão de pesquisa: como as facções partidárias comunicam posições de dissenso interno nas mídias sociais?

HP1: No caso das negociações pré-eleitorais para a disputa da prefeitura do Rio de Janeiro, espera-se encontrar no Facebook canais específicos de facções do PSOL que articularam campanhas públicas contra negociações feitas pela cúpula do partido pela unificação da chapa de esquerda na cidade.

HP2: Hsu e Park (2011) defendem que redes de associação (following network) representam aproximações simbólicas e políticas entre atores políticos na internet. Esperamos que os canais da esquerda do Rio de Janeiro no Facebook apresentem conexões majoritariamente com pares do próprio partido no Facebook.

HP3: Em conjunturas de dissenso interno acerca de negociações interpartidárias pela criação de alianças e maximização dos votos, facções policy-seeking tornam pública a insatisfação nas mídias sociais e geram um processo de ruídos, críticas e desgaste no campo ideológico.

\section{Coleta de dados}

Com a finalidade de tensionar os questionamentos empiricamente, este artigo desenvolve uma pesquisa de caráter exploratório, a partir de um estudo de caso, com o seguinte desenho metodológico: (1) mapear a presença digital das lideranças partidárias, se existentes, do PT, do PCdoB, do PSOL e da Rede no Facebook. Nesse ponto, o artigo não se limitou somente às páginas oficiais dos partidos, mas investigou também páginas de lideranças estaduais, diretórios locais e, sobretudo, facções. Optamos por inserir na amostra as lideranças porque Freixo, Jandira e Molon foram as principais vozes em favor da aliança, enquanto Babá, vinculado ao PSOL, foi o seu crítico mais ativo; (2) analisar as redes de filiação desses canais, ou seja, como constroem pontes de conexão entre si; e (3) estudar os posicionamentos utilizados nas postagens realizadas sobre a união das esquerdas com atenção ao tratamento dado aos partidos. O Facebook foi escolhido como objeto empírico para o artigo porque resultados de pesquisas anteriores evidenciaram que é a plataforma mais utilizada por políticos e partidos em contexto nacional (Braga, Rocha e Carlomagno, 2015). 
O mapeamento das páginas das lideranças e facções partidárias da esquerda no Facebook foi realizado a partir de consultas à Search API da plataforma utilizando os nomes em listas elaboradas pela literatura especializada. Morais (2014) elenca as seguintes facções do PSOL:

Ação Popular Socialista (APS), com duas divisões: comunista e Nova Era;

Movimento da Esquerda Socialista (MES);

Coletivo Rosa Zumbi;

Insurgência;

Corrente Socialista dos Trabalhadores (CST);

Coletivo Revolucionário Socialista (CRV);

Tendência de Luta Socialista (TLS-SP);

Coletivo Primeiro de Maio (SP);

Coletivo Fortalecer PSOL (SP-RS);

Coletivo Brasil Real (PE);

Liberdade, Socialismo e Revolução (LSR).

Sobre o PSOL, encontramos 54 fanpages que atendem aos critérios da pesquisa. Repetimos o procedimento para PT, PCdoB e Rede, chegando ao total de 189 canais da esquerda do Rio de Janeiro no Facebook.

A segunda etapa é a análise de redes sociais dos laços de filiação entre as fanpages de lideranças e facções existentes no Facebook ${ }^{6}$. Segundo Recuero (2009, p. 98), redes associativas, ou de filiação, são formadas por conexões estáveis, referentes ao pertencimento a determinado grupo. Literatura relacionada demonstra que essas ligações são proxies de posicionamentos políticos. Estudos empíricos anteriores demonstraram que hiperlinks representam, em alguma medida, posicionamentos ideológicos, com valor simbólico sobre o ator político e o universo em que se insere (Hsu e Park, 2011; Ackland e Gibson, 2013). Barberá (2015) também utilizou análise de redes e a estrutura de conexões entre os atores no Twitter para estimar seu posicionamento ideológico, tanto entre a elite como entre o público, durante a eleição presidencial estadunidense de 2012.

Utilizamos duas medidas da análise de redes sociais nessa etapa: (1) a centralidade de autovetor, que avalia o posicionamento dos nós na rede a partir da qualidade das conexões estabelecidas; e (2) o algoritmo de modularidade de Louvain, que divide a rede em subagrupamentos de acordo com a densidade das conexões. Para visualizar a rede,

\footnotetext{
${ }^{6}$ As conexões entre os canais no Facebook foram coletadas a partir do Módulo Page Like Network do aplicativo Netvizz. A ferramenta extrai dados relativos às páginas que os partidos seguem no Facebook. Ou seja, assim como os usuários, as fanpages podem "curtir" outras fanpages. Isso só pode ser realizado pela administração do canal. As páginas seguidas são expostas publicamente na seção "Curtidas desta Página" no Facebook. Quando uma página curte a outra, ela passa a receber todas as publicações realizadas em sua linha do tempo, tornando mais fácil o acompanhamento diário dessas postagens. Além disso, estabelece ligações entre um conjunto de atores para futuras referências, trocas de informações e compartilhamento de publicações. É uma atividade que cumpre função semelhante ao "Blogroll" dos blogs e às seções de links de instituições parceiras, geralmente disponíveis em sites e blogs.
} 
aplicamos um algoritmo de força gravitacional chamado Force Atlas $2 \mathrm{com}$ a finalidade de identificar o desenho estrutural a partir da configuração e da densidade das conexões (Blondel et al., 2008). A seleção desse modelo de visualização se justifica com o objetivo de elucidar as relações de força entre nós de redes de diferentes partidos.

Por fim, coletamos todas as postagens das 189 fanpages listadas na primeira etapa durante os dias 15 de abril e 15 de julho de 2016. São 3.950 publicações referentes aos mais variados temas que não tratavam do objeto dessa pesquisa. Por isso, filtramos apenas aquelas que citavam a união das esquerdas no Rio de Janeiro, a partir de palavras-chave como: "esquerda", "união", "unidade", "Molon", "Freixo" e "Jandira". O banco de dados resultante dessa filtragem possui 44 postagens. Os posicionamentos foram investigados pela análise de conteúdo a partir da construção de três categorias (Favorável, Desfavorável, Ambíguo $)^{7}$.

\section{Resultados e análise}

Organizamos a apresentação dos resultados em três eixos: (1) presença do PSOL e suas organizações internas no Facebook; (2) análise de redes de esquerda no Rio de Janeiro; e (3) estudo das publicações contrárias e favoráveis à chapa única de esquerda.

\section{Organização do PSOL no Facebook}

Na primeira etapa, investigamos como o PSOL está presente e se organiza no Facebook. Para guiar esse levantamento, utilizamos as categorias: (1) diretórios - laranja; (2) vereadores e deputados - roxo; (3) setoriais - amarelo; (4) núcleos locais - verde; (5) movimentos - vermelho; (6) sindicato - laranja; e facções - azul. O resultado mostra a estrutura topológica sobre a conexão entre os atores no Facebook, e o tamanho dos nós está dimensionado pelo grau de centralidade de autovetor (quantidade de ligações direcionadas para o canal) - Figura 1 :

\footnotetext{
7 Essas categorias constam em livro de códigos com a operacionalização, instruções para codificação e o teste de confiabilidade, que foram construídas em pesquisa anterior e aplicadas para compreender as controvérsias temáticas, combinando análise de conteúdo e de redes sociais.
} 
Figura 1

Rede PSOL no Facebook

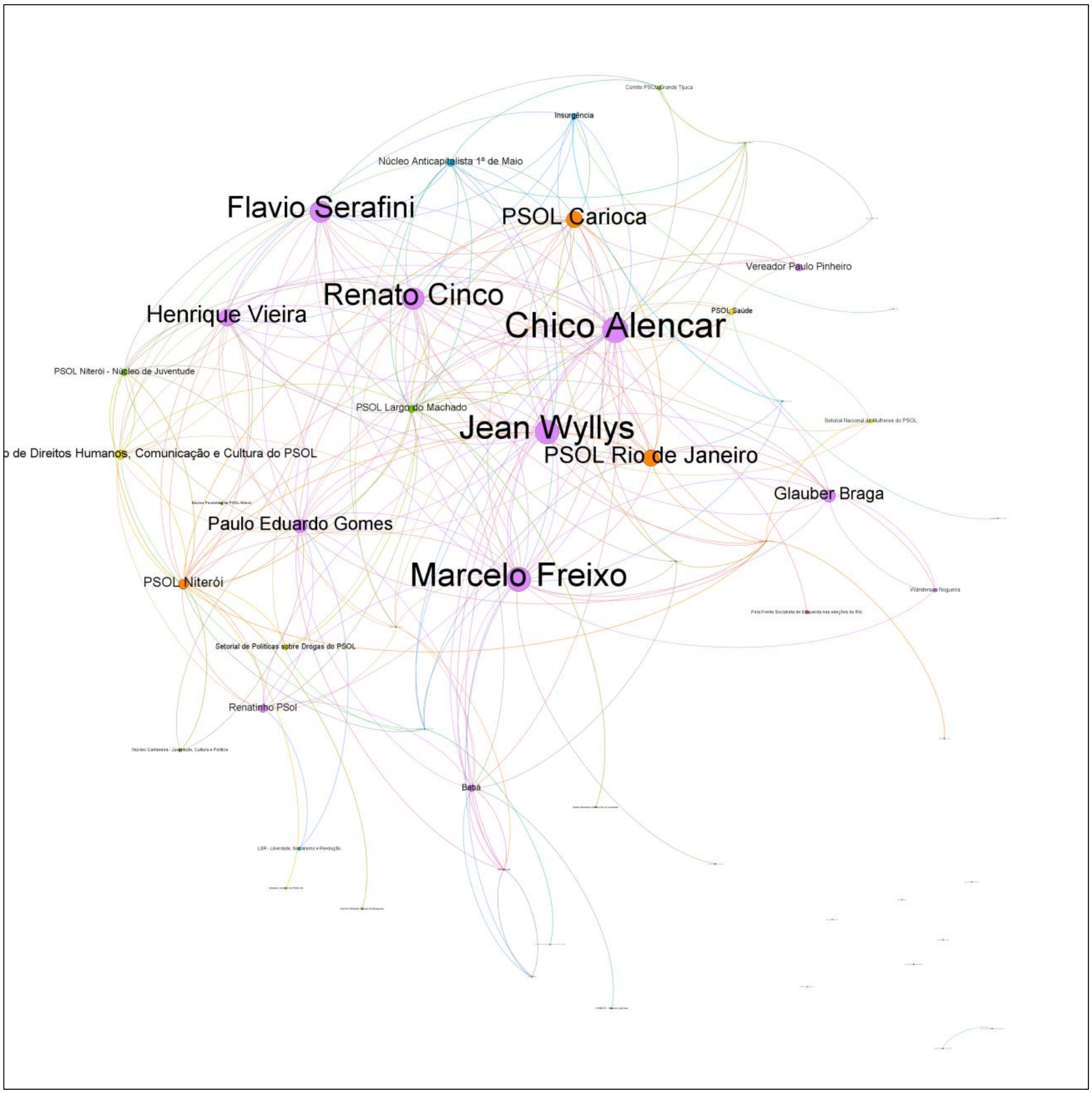

Fonte: Facebook Graph API. 
O panorama da rede demonstra a representação da organização partidária do PSOL no Facebook. O centro é ocupado pelas lideranças, como Marcelo Freixo, Jean Wyllys e Chico Alencar. É possível identificar uma clusterização à esquerda com parlamentares de Niterói, como Paulo Eduardo Gomes, Henrique Vieira e Flávio Serafini. Já a parte sul da rede contém menos pontos de conexão em comum com o resto da estrutura. Estão localizadas naquela região as facções e seus aparelhos partidários, como Babá, Corrente Socialista dos Trabalhadores (CST), Combate (braço sindical) e Liberdade, Socialismo e Revolução (LSR).

De fato, há fanpages de comunicação de nove facções do PSOL no Facebook: Luta Socialista; Núcleo Anticapitalista $1^{0}$ de Maio; Liberdade, Socialismo e Revolução (LSR); Insurgência; Coletivo Primeiro de Maio; Coletivo Rosa Zumbi; Ação Popular Socialista (APS); Corrente Socialista dos Trabalhadores (CST); e Movimento Esquerda Socialista (MES). O resultado vai na direção da primeira hipótese deste artigo: de acordo com a fragmentação partidária, as facções mais institucionalizadas desenvolvem seus próprios canais digitais de comunicação. Além disso, todas as facções do PSOL possuem uma página no Facebook, padrão não encontrado nos demais partidos no Rio de Janeiro. De fato, houve muito mais visibilidade dos grupos faccionalizados do PSOL, enquanto os demais partidos se comunicavam pelos canais dos diretórios ou das lideranças.

Podemos aprofundar esse achado ao analisar a média de centralidade de autovetor de acordo com as categorias dos atores. As páginas foram codificadas em: (1) vereadores e deputados (representando $27,78 \%$ do total); (2) núcleos locais $(22,22 \%)$; (3) facções $(18,52 \%)$; (4) setoriais $(14,81 \%) ;(5)$ diretórios $(9,26 \%) ;(6)$ movimentos $(5,56 \%)$ e sindicato $(1,85 \%)$.

Figura 2

Média de centralidade de autovetor por categoria

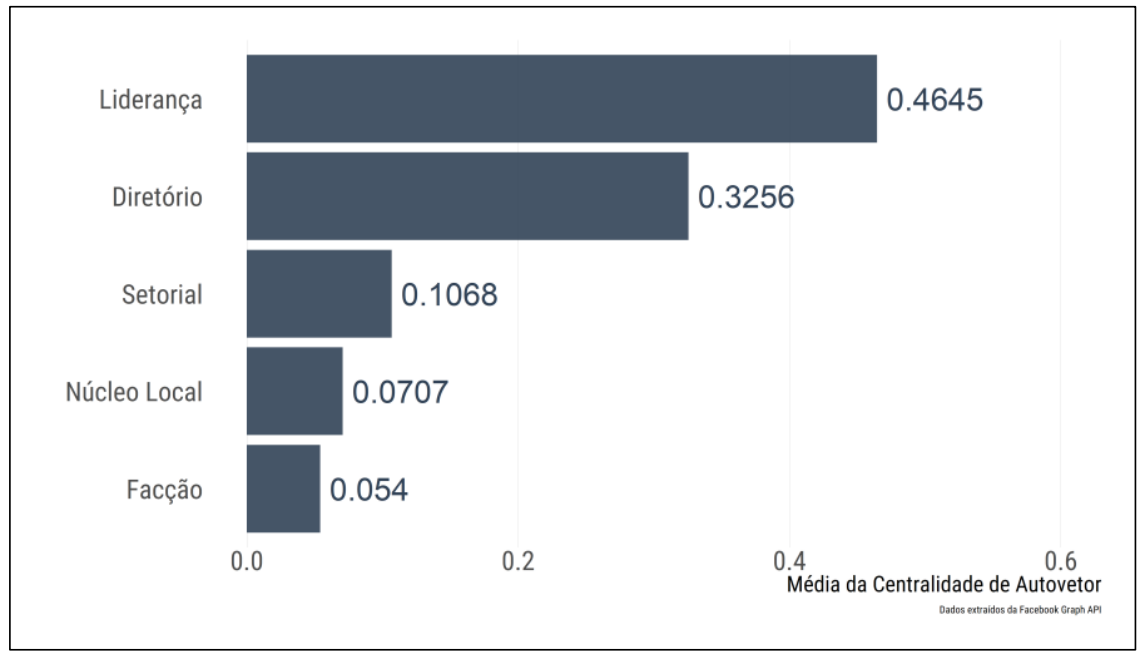

Fonte: Facebook Graph API. 
A Centralidade de Autovetor é uma medida da análise de redes sociais que atribui um valor de 0 a 1 pela qualidade das ligações realizadas pelos atores. Em nossa amostra, a maior média pertence às lideranças, 0,4645, seguidas dos diretórios, 0,3256, e das setoriais temáticas (direitos humanos, comunicação, juventude, saúde), com 0,1068. As facções aparecem depois de núcleos locais, com 0,054, à frente apenas de movimento e sindicato, categorias residuais com apenas três fanpages. Esse achado fortalece a sustentação da primeira hipótese, evidenciando que as facções ocupam posicionamento periférico, considerando as conexões estabelecidas por atores partidários no Facebook. Além disso, evidencia que as conexões entre os pares no Facebook favorecem as lideranças pessoais em detrimento dos espaços organizacionais, nesse caso, da esquerda no Rio de Janeiro.

A esquerda do Rio de Janeiro no Facebook

Antes de analisar o conteúdo das publicações, repetimos o mesmo procedimento de coleta das ligações entre canais, adicionando à amostra também os agentes do PT, do PCdoB e da Rede. O objetivo foi entender se outros partidos também possuem facções locais ativas no Facebook e como se configura o panorama macro de conexões interpartidárias. Nesse sentido, espera-se, ao analisar a presença digital comparada de outros partidos e de seus componentes, entender em que medida a publicização das facções é algo particular do PSOL na cidade. A Figura 3 apresenta 189 fanpages com 880 ligações entre si. O particionamento das comunidades foi realizado a partir do algoritmo de modularidade de Louvain, disponível no aplicativo de análise de redes sociais Gephi. 


\section{Figura 3}

\section{Mapeamento de PSOL, PT, PCdoB e Rede}

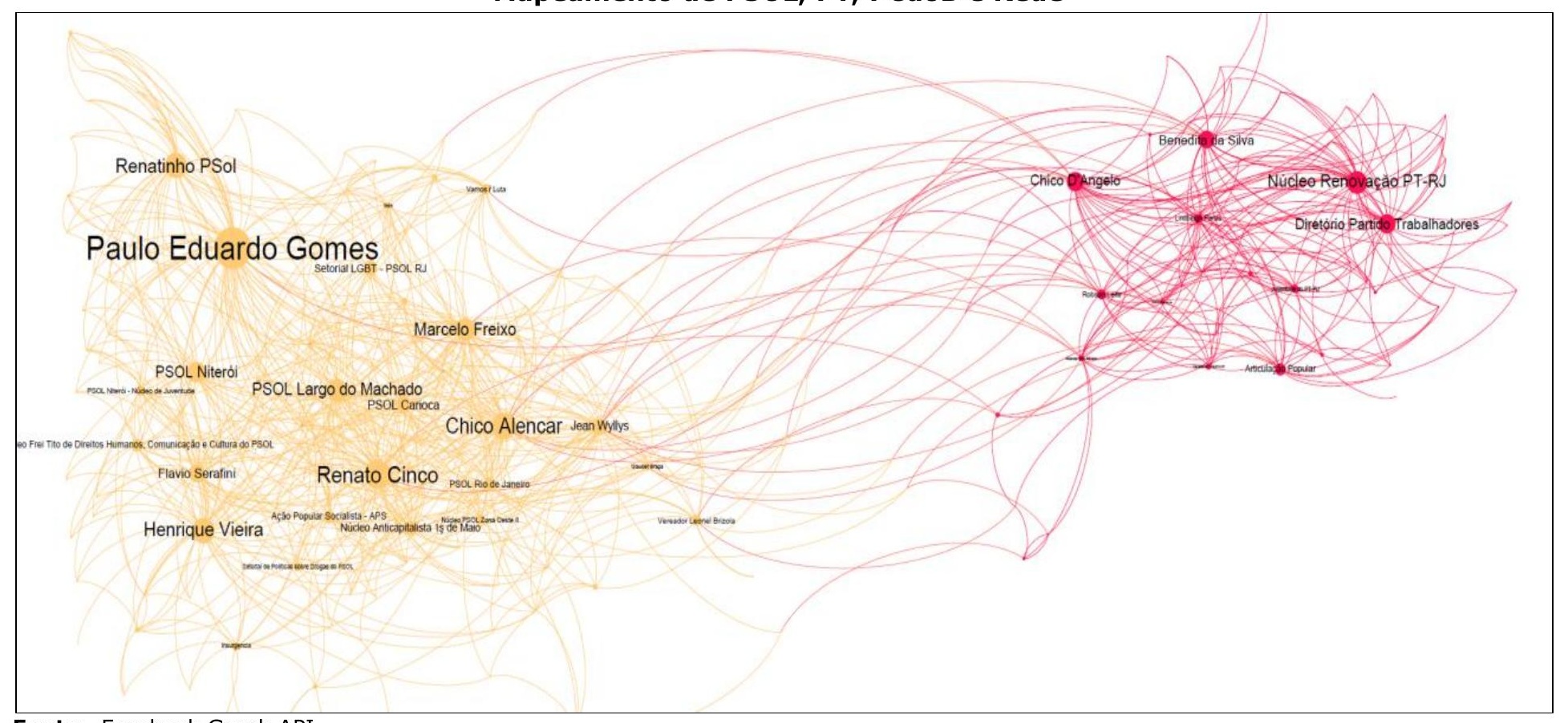

Fonte: Facebook Graph API.

O panorama dessa rede das esquerdas do Rio de Janeiro no Facebook mostra uma nítida cisão entre dois clusters: (a) há um grande agrupamento de agentes do PSOL, em laranja, que representa $68,78 \%$ da amostra; e (b) um grupo menor, pertencente ao PTPCdoB, em vermelho, com 31,22\%. Outro ponto interessante é que o agrupamento da Rede e de Alessandro Molon não é numeroso o suficiente para criar um cluster separado dos demais e acaba sendo atraído para o lado petista. A segunda hipótese - que sustenta que as conexões seguem as linhas partidárias - é parcialmente confirmada. Encontramos uma fragmentação entre canais do PT e do PSOL, mas Rede e PCdoB não geraram outro cluster: Rede possivelmente pelo breve período de fundação e pouco enraizamento social, e PCdoB por conta de sua integração política com o PT. Além disso, é possível perceber como a rede PSOL é mais densa que as dos outros partidos. Não há a mesma presença de páginas de facções partidárias do Rio de Janeiro no Facebook no caso de PT, PCdoB e Rede, na medida em que esse grupo está mais fortemente articulado em torno da atuação personalizada de suas lideranças. 
Os pré-candidatos Marcelo Freixo (PSOL), Jandira Feghali (PCdoB) e Alessandro Molon (Rede) divulgaram vídeos no Facebook depois de uma reunião no dia 3 de junho de 2016. Nela, haviam decidido que não se atacariam no primeiro turno e que, no segundo turno, os derrotados manifestariam apoio formal ao candidato de esquerda que fosse ao segundo turno. A partir daí, foram iniciadas duas campanhas nas mídias sociais: uma favorável à unificação das chapas, mobilizada pelas lideranças do PT, do PSOL, do PCdoB e da Rede, e outra contrária, articulada por facções do PSOL. No dia seguinte, dissidentes internos no PSOL criticaram o encontro pelas redes e o caso ganhou escala pública na cidade, sendo coberto pela imprensa como uma disputa fratricida nos termos: "PSOL versus PSOL". Nesta subseção, analisaremos as publicações coletadas no Facebook sobre as negociações, as críticas feitas pelas facções do PSOL e a anulação do acordo.

A análise de conteúdo apresentada na Tabela 1 demonstra que a maioria das publicações no Facebook era favorável à unificação das chapas. Na prática, havia manifestações públicas de apoio do PT, do PCdoB, da Rede e de parte do PSOL. Não encontramos nenhuma publicação contrária ao bloco nas páginas de componentes do PT, do PCdoB e da Rede. Especialmente, deputados do PT e do PCdoB foram os mais enfáticos em defender a estratégia, fazendo campanha aberta com cartas e apelos públicos. A reação desfavorável veio particularmente de facções do PSOL e, com mais intensidade, do então vereador Babá.

\section{Tabela 1}

\section{Frequência simples da análise de conteúdo}

\begin{tabular}{|l|c|c|}
\hline Codificação & Posts & Percentual (\%) \\
\hline Favorável & 31 & 70,5 \\
\hline Contrário & 13 & 29,5 \\
\hline
\end{tabular}

Fonte: Facebook Graph API.

A página do PSOL do diretório municipal do Rio de Janeiro divulgou no dia 3 de junho um vídeo em que Marcelo Freixo fala sobre o encontro com Jandira e Molon. No mesmo dia, o então deputado estadual publicou um texto, com mais de 160 compartilhamentos, relatando a pauta do encontro e negando que tenham debatido a chapa única. O parlamentar argumentou que discutiu um projeto de transformação para a cidade e informou que seriam marcados outros encontros em breve, o que não aconteceu ${ }^{8}$. Jean Wyllys divulgou, no dia 4, o texto "Rio de Janeiro: não é hora de sectarismos", explicando que, em sua visão, há muitas diferenças entre o PSOL e os demais partidos, mas que não deveria haver ataques e que um acordo de apoio mútuo no segundo turno seria importante para frear o conservadorismo.

\footnotetext{
${ }^{8}$ Disponível em: <https://www.facebook.com/MarceloFreixoPsol/posts/1192505077456413>. Acesso em:
} 12 out. 2019. 
Além disso, lideranças do PT, do PC do B e da Rede também se manifestaram em favor do acordo. O deputado federal pelo PT-RJ, Wadih Damous, postou duas cartas à militância pedindo chapa única, uma delas intitulada "Em busca da necessária unidade":

Aqui no Rio de Janeiro, defendo que toda a esquerda se una nas eleições municipais, independentemente de quem ocupe a cabeça de chapa. É necessário reconhecer que o PT errou ao simplesmente apoiar uma aliança cujo resultado geral era distinto do programa petista. Como foi equivocada a decisão do partido de abrir mão da crítica e da denúncia em questões como a lógica da "cidade-negócio" e as remoções arbitrárias (Damous, 2016) ${ }^{9}$.

Jandira Feghali fez três publicações defendendo a importância da união dos partidos de esquerda. Em "A busca pela unidade", defende chapa única no Rio de Janeiro, argumentando pela arregimentação de "trabalhadores, negros, aposentados e LGBTs" como uma forma de combater os retrocessos do governo de Michel Temer e enfrentar as candidaturas conservadoras. O então vereador por Niterói, Babá, realizou uma publicação no Facebook contrapondo o texto de Feghali, chamando-a de "demagoga" e afirmando que recebeu verbas nas eleições de 2010 e 2014 de empresas investigadas pela Operação Lava-Jato e que o PCdoB representa um: "governismo decadente, desesperado, oportunista e hipócrita, que só busca unidade com o PSOL após terem sido escorraçados do poder pelos velhos e reacionários ex-aliados do PMDB, PP e outras legendas fisiológicas e corruptas" (Babá, 2016, s.p) ${ }^{10}$.

Molon, por sua vez, fez duas postagens relatando as conversas da reunião com Freixo e Feghali. Em seu texto, faz um apelo pela união de forças progressistas em prol do Rio de Janeiro: "Abrimos um espaço de diálogo constante entre nós. Esse espaço é necessário, mas não suficiente. Entendo que é preciso ouvir outras vozes progressistas que possam contribuir para a construção de um Rio que seja melhor não para um grupo, mas para todos" (Molon, 2016, s.p) ${ }^{11}$.

A reunião entre os três candidatos deflagrou fortes reações de diversas alas do PSOL. No dia seguinte à reunião, a CST divulgou em seu site e Facebook a nota "Não em nosso nome", em que ataca o encontro e o compromisso de não agressão e apoio mútuo no segundo turno. "Consideramos que não há nada de esquerda ou progressivo com PT, PCdoB e Rede. E muito pior porque essa movimentação prejudica, atrasa e destrói a possibilidade real de surgir uma alternativa que apareça para a população" (CST, 2016) $)^{12}$.

\footnotetext{
${ }^{9}$ Disponível em: <https://www.facebook.com/wadihdamous/posts/676713732466389>. Acesso em: 12 out. 2019.

10 Disponível em:

<https://www.facebook.com/babapsol/photos/a.302939273109185.65172.290375317698914/969715986 431507>. Acesso em 12 de out. 2019

11 Disponível em: <https://www.facebook.com/MolonRJ/videos/1035978346495654/>. Acesso em 12 out. 2019

12 Disponível em: <https://www.facebook.com/cstpsol/posts/1196253403751064>. Acesso em: 12 out. 2019.
} 
O vereador niteroiense Babá foi o mais engajado no assunto, publicando cinco textos com média de 772 compartilhamentos cada. Ele chamou a iniciativa de Jandira Feghali de "oportunista e demagógica" e considerou a chapa unificada um erro categórico:

É UM ERRO CATEGÓRICO SE UNIR A JANDIRA E MOLON | Os ex-governistas do PT e PCdoB, isolados por seus ex-aliados corruptos e reacionários do PMDB e PP, ex-ARENA, tentam usar de todas as formas o PSOL como bote salvavidas frente à decadência política e ao rechaço popular em que se encontram. A Rede é o partido de Marina, que apoiou o corrupto Aécio no segundo turno (Babá, 2016) ${ }^{13}$.

No dia 7 de junho, em represália ao acordo dos candidatos, correntes do PSOL lançaram o "Manifesto pela Frente Socialista de Esquerda nas eleições do Rio de Janeiro Pela rejeição categórica de qualquer aliança política com PT, PCdoB, Rede e demais partidos da ordem"14. O texto é assinado por quatro vereadores, Babá, Renato Cinco, Paulo Eduardo Gomes e Renatinho, além de seis facções: Corrente Socialista dos Trabalhadores (CST); Liberdade, Socialismo e Revolução (LSR); Luta Socialista (LS); Liberdade e Revolução Popular (LRP); Nova Organização Socialista (NOS); e o Coletivo Ecossocialista Libertário (Ecossol). A disputa interna se tornou pública também na imprensa por meio da coluna de Berenice Seara, intitulada "PSOL versus PSOL" (Seara, 2016), relatando o racha entre Jean Wyllys e Babá.

O texto foi publicado no site das facções e dos parlamentares signatários no dia 7 e circulou nas mídias sociais a partir da mobilização de uma campanha com uma fanpage no Facebook chamada "Pela Frente Socialista de Esquerda nas eleições do Rio", que atraiu em torno de 500 curtidas, para divulgar o manifesto e relatar as plenárias internas do PSOL. Assim, além de divulgar os textos contrários ao acordo de Freixo, apoiado publicamente por Jean Wyllys, com PT, PCdoB e Rede, as facções do PSOL também passaram a criticar as lideranças desses partidos e pedir uma chapa ideologicamente homogênea para a prefeitura do Rio de Janeiro.

O manifesto se posiciona fortemente contrário a qualquer aliança ou acordo com PT, PCdoB e Rede e repudia o encontro entre Freixo, Molon e Jandira. Segundo o argumento, a reunião e a pauta não haviam sido aprovadas pelos mecanismos de decisão de base do PSOL e Freixo não poderia assumir acordos sem cumprir esse procedimento. Além da exposição pública da insatisfação interna das facções, o documento enfatizou críticas ásperas contra os demais candidatos do campo da esquerda:

\footnotetext{
13 Disponível em: <https://www.facebook.com/babapsol/videos/976087752460997/>. Acesso em: 12 out. 2019.

14 Disponível em: <http://cstpsol.com/home/index.php/2016/06/07/manifesto-pela-frente-socialista-deesquerda-nas-eleicoes-do-rio-de-janeiro-em-2016pela-rejeicao-categorica-de-qualquer-alianca-politicacom-pt-pcdob-rede-e-demais-partidos-da-ordem/>. Acesso em: 12 out. 2019.
} 
Não podemos acreditar num súbito giro à esquerda do PT, do PCdoB e de outras agremiações que se apresentam como alternativa, como é o caso da REDE. Neste sentido, não podemos admitir uma relação fraternal com essas agremiações, deixando de denunciar que elas fizeram parte do bloco político, junto com o PMDB, que afundou o país e o Rio de Janeiro. Até hoje, o PT participa da gestão de Eduardo Paes. Por isso, avaliamos ter sido um grande erro a presença do PSOL na reunião realizada no dia 03/06, que agrupou Marcelo Freixo, Jandira Feghali (PCdoB), Alessandro Molon (REDE) e Quaquá (presidente do PT-RJ). Tal reunião de fato selou, mesmo que não se expresse em coligações formais no primeiro turno, uma aliança política entre estes setores (pacto de não agressão, compromissos de apoios no segundo turno etc.), já rejeitada pelo congresso estadual do partido. Pior: tanto a participação na reunião quanto as posições assumidas foram adotadas sem passar pela base e pelas instâncias democráticas do PSOL (Manifesto, 2016, grifo nosso $)^{15}$.

A campanha liderada por Babá e outras facções psolistas se opôs à união com PCdoB, PT e Rede em função de defender a homogeneidade do bloco que chamam de "esquerda socialista". Essa ação marca o posicionamento dos atores contra as alianças entre PT, PCdoB e o PMDB no Rio de Janeiro, ao mesmo tempo em que advoga por outra forma de governar e outras pautas. Isso pode ser interpretado pela chave de análise do posicionamento policy-seeking do partido. Nesse sentido, o argumento principal foi que disputar a eleição ao lado desses partidos representaria grandes concessões programáticas, na medida em que PT e PCdoB fizeram parte da gestão de Eduardo Paes e a Rede apoiou Aécio Neves (PSDB) no segundo turno do pleito presidencial de 2014.

As negociações intrapartidárias entre as facções se arrastaram pelo mês de junho. No dia 19, houve reunião do diretório municipal do PSOL e os signatários do manifesto voltaram a divulgar nota contra a chapa única de esquerda:

PT, PCdoB e REDE estiveram juntos com o PMDB e o PSDB votando o ajuste fiscal que penaliza o povo. Neste sentido, o PSOL Carioca não manterá uma relação fraternal com essas agremiações. Não compomos um mesmo campo. Não deixaremos de denunciar que elas fizeram parte do bloco político, junto com o PMDB, que afundou o país e o Rio de Janeiro. Portanto, não estabeleceremos pactos de não agressão com PT, PC do B e REDE na próxima eleição municipal do Rio. Ou seja, combateremos de igual forma as candidaturas de Pedro Paulo, de Crivella e de Romário, bem como de Jandira e Molon. Ao mesmo tempo, não assumiremos compromissos de apoios aos

\footnotetext{
15 Nota publicada no site da CST e divulgada nas páginas da facção, de Babá e do Manifesto no Facebook. Disponível em: <http://cstpsol.com/home/index.php/2016/06/07/manifesto-pela-frente-socialista-deesquerda-nas-eleicoes-do-rio-de-janeiro-em-2016pela-rejeicao-categorica-de-qualquer-alianca-politicacom-pt-pcdob-rede-e-demais-partidos-da-ordem/>. Acesso em: 12 out. 2019.
} 
candidatos a prefeito dessas organizações no segundo turno (Manifesto, 2016, ver nota 15).

Na votação em plenária interna, os acordos realizados por Marcelo Freixo foram desfeitos e o PSOL aprovou a coalizão diminuta somente com o PCB. Em seguida, as negociações pela unificação das chapas foram encerradas e Jandira Feghali saiu como candidata pelo PCdoB e Alessandro Molon pela Rede. A Figura 4 evidencia o papel fundamental das lideranças parlamentares para disseminar os posicionamentos no Facebook. Os principais canais com publicações mais compartilhadas são os de Jandira Feghali, Alessandro Molon, Marcelo Freixo, do então senador pelo PT Lindbergh, do deputado federal Wadi Damous e do vereador e líder da CST, Babá. Também aparecem entre os primeiros as páginas da facção CST e do PSOL Carioca:

Figura 4

Média de compartilhamentos das publicações no Facebook

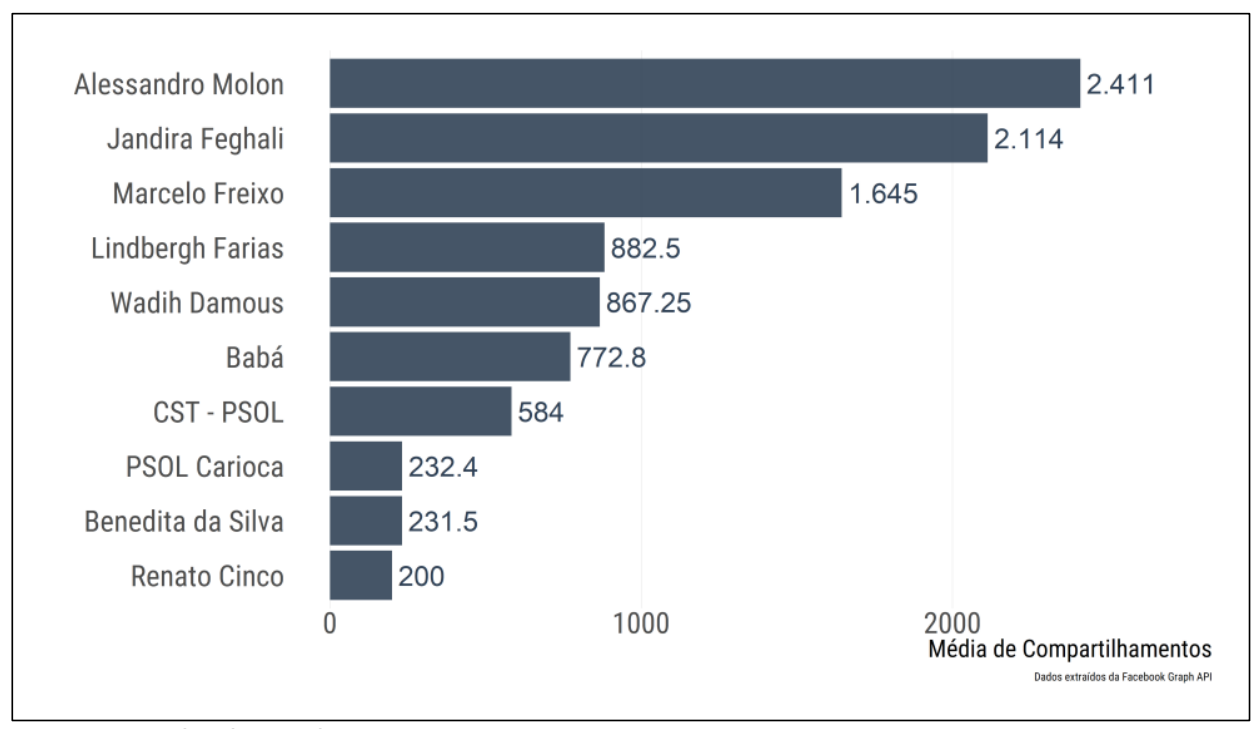

Fonte: Facebook Graph API.

O estudo exploratório realizado pelo artigo demonstra a organização estrutural de redes partidárias que representam e reconstroem a distribuição de visibilidade intrapartidária, de um lado, e interpartidária, de outro. Nesse sentido, identificamos como as facções do PSOL e suas lideranças fizeram campanha publicamente contra a chapa única e o acordo de evitar ataques no primeiro turno. Nesse caso, a publicização de discordâncias internas no PSOL, por meio da comunicação de facções partidárias e de seus líderes, mobilizou a militância em campanha digital contra a unificação eleitoral no Rio de Janeiro, inclusive por meio da criação de uma fanpage dedicada especialmente ao assunto, com a finalidade de evitar a unificação. Principalmente, durante a reunião entre os três candidatos, foi possível encontrar diversas lideranças e militantes psolistas criticando o 
tangenciamento das decisões tomadas em plenárias e externando a insatisfação, inclusive com campanha sistemática por uma "união socialista", bloco programático com o PCB. Além disso, mostramos como os dados das mídias sociais podem jogar luz sobre comportamentos partidários e sobre a circulação de informações políticas em período de pré-campanha.

\section{Discussão}

Os dados apresentados evidenciam uma mudança na lógica da campanha eleitoral, tal como ela se verifica no ambiente das mídias sociais, em comparação com a propaganda eleitoral gratuita no rádio e na televisão (HGPE). O primeiro ponto a se destacar diz respeito aos agentes que têm voz e acesso ao público. O HGPE reforça o papel da direção partidária como lugar de coordenação e distribuição de poder político no interior dos partidos (Albuquerque, Steibel e Carneiro, 2008); alternativamente, as mídias sociais permitem que facções exerçam influência indireta no processo de comunicação, para além do controle exercido pela direção partidária. Um segundo ponto diz respeito à natureza do processo de circulação das mensagens. No modelo de broadcasting, o público atingido pela mensagem política é mais universal, pois corresponde à audiência do rádio e da televisão aberta sintonizada no momento da transmissão; nas mídias sociais, por sua vez, a circulação de mensagens depende da existência de canais de comunicação preexistentes (links) entre os diversos agentes que atuam nelas, bem como da ação de compartilhamento dos pares e do público para que as mensagens ganhem visibilidade.

Três elementos podem ser destacados nos resultados. Em primeiro lugar, assim como apontado por Hsu e Park (2011), a análise de redes sociais evidencia a formação de clusters partidários, no caso nacional demonstrando a distância entre os subsistemas comunicativos estruturados em torno do PSOL e do PT-PCdoB. Longe de ser uma característica necessariamente digital, essa distância reflete os padrões históricos de conflito e afastamento entre os partidos, como analisados por Morais (2014), desde a fundação do PSOL, visto que este construiu a sua identidade política principalmente em oposição ao PT. A abordagem organizacional da comunicação política em âmbito digital analisa essencialmente a relação entre o uso dessas ferramentas e os objetivos e condições concretas dos partidos.

Um segundo aspecto digno de nota diz respeito à presença das facções partidárias da rede do PSOL. Isso não se replica em nenhum dos demais partidos observados neste artigo. Como visto em Ceron (2017), as mensagens postadas nas mídias sociais são fonte válida de observação para entender as dinâmicas internas dos partidos e as preocupações com a heterogeneidade ideológica em coalizões. No caso do Rio de Janeiro, um partido altamente faccionalizado como o PSOL terá uma fragmentação em seus canais de comunicação, publicizando controvérsias internas e críticas contra lideranças que disputam o espectro ideológico. 
O terceiro achado aponta para o aspecto de personalização da comunicação política nas mídias sociais. Nesse sentido, cabe debater o paradoxo entre o modelo de ação conectiva, como proposto por Bennett e Segerberg (2012), que privilegia as conexões individuais, e o modelo de ação coletiva, que pressupõe a formação de consensos e acordos coletivos necessários para a mobilização. O confronto entre essas lógicas partidárias tradicionais e digitais traz consequências para a democracia contemporânea, como a exposição pública de ruídos, críticas e controvérsias que antes ficavam restritas aos âmbitos internos dos partidos. Tal modelo de racionalidade individualista faz com que campanhas sejam mobilizadas pelas redes para contrariar as decisões da direção, como o posicionamento de Freixo em favor da candidatura única.

Do ponto de vista do debate sobre a conveniência ou não de uma aliança de esquerdas, essa questão favoreceu um discurso que destacava a consistência de um posicionamento ideológico estreito - em nível federal, estadual ou municipal - em contraste com os demais partidos (principalmente o PT), cuja abordagem catch all da política foi sistematicamente apresentada pelos opositores da aliança como prova de incoerência e descompromisso com os ideais da esquerda. Em particular, o achado referente aos compartilhamentos chama a atenção para o papel relevante que lideranças do PSOL em Niterói, município vizinho ao Rio de Janeiro, desempenharam nesse processo.

Nesse sentido, embora as mídias sociais viabilizem a vocalização das demandas e insatisfações, isso não necessariamente se traduz em fortalecimento ou melhoria das decisões intrapartidárias, na medida em que a barganha externa gera ruídos e estimula controvérsias e hostilizações dentro do campo ideológico, enfraquecendo os posicionamentos da direção e a coordenação das estratégias.

\section{Conclusões}

O presente artigo explorou a comunicação partidária nas mídias sociais, tendo por referência o debate em torno da montagem de uma aliança das candidaturas de esquerda na eleição de 2016 para a prefeitura do Rio de Janeiro. Nas duas últimas décadas, a pesquisa sobre o uso da internet como ferramenta de comunicação pelos partidos políticos produziu um volume significativo de trabalhos em vários países. De modo geral, pode-se dizer que as questões que nortearam a investigação original - o potencial da internet para promover uma democratização das relações intrapartidárias, dando mais voz ao cidadão comum, bem como um maior equilíbrio nas relações interpartidárias - permanecem centrais na agenda de investigação.

Alternativamente, este artigo procurou explorar o assunto com base em uma perspectiva analítica distinta, tendo em vista dois aspectos principais. Em primeiro lugar, ele emprega uma abordagem organizacional da comunicação partidária, que considera o uso político da internet menos em função do seu potencial de promover uma mudança qualitativa na natureza da atividade política do que da sua capacidade de servir como 
recurso estratégico a serviço de interesses políticos particulares. Em segundo lugar, ele aborda especificamente a dinâmica das mídias sociais, em vez da "internet", considerada de forma mais geral. Com base nisso, exploramos o modo como o uso das mídias sociais se constitui como fator de fortalecimento do poder de comunicação política das facções e lideranças particulares que compõem o PSOL em relação à liderança formal do partido.

Os resultados da investigação sugerem que as mídias sociais possibilitaram que, dada a fragmentação interna do PSOL, suas facções tangenciem a hierarquia organizacional e manifestem insatisfações e controvérsias publicamente como forma de mobilizar militantes contra as decisões da direção. Isso ocorre porque, ao contrário do que acontece com a propaganda política no rádio e na televisão, e de maneira muito mais eficiente que os websites de partidos, as mídias sociais permitem a agentes particulares quebrar o monopólio comunicativo da liderança formal dos partidos. Por esse motivo, elas têm o potencial de oferecer visibilidade pública a dissensos e confrontos internos entre diferentes facções partidárias e entre os partidos e suas lideranças. Por outro lado, cabe questionar se essa lógica comunicativa efetivamente favorece a democracia no partido, uma vez que fanpages de facções ou de lideranças com boa inserção na rede (em termos tanto do seu número de seguidores quanto da estrutura de links nas quais elas estão inseridas) podem exercer influência política, ignorando os mecanismos institucionais de tomada de decisão característicos da vida partidária.

Essa estrutura de comunicação encontra no PSOL-RJ um caso paradigmático, dado que o partido se estrutura em torno de facções organizadas e de sua forte presença nas mídias sociais, muito mais expressiva do que a do campo político representado por PT e PCdoB. O resultado da análise de redes sociais evidencia uma nítida separação entre as redes do PSOL e do PT-PCdoB nas mídias sociais, e identifica os aparatos comunicacionais de facções como condições para a articulação de campanhas públicas contra sinalizações da direção. A reação dos dissidentes denunciava a aliança com PT-PCdoB como uma traição aos seus ideais de esquerda, dada a política de alianças ampla, catch all, que caracterizava esses partidos nos ambientes da política nacional, estadual e do município do Rio de Janeiro.

O presente artigo possui algumas limitações que devem ser levadas em consideração. Em primeiro lugar, não objetiva estabelecer uma relação de nexo causal entre fatores tecnológicos e organização partidária. Nesse sentido, não argumentamos que as mídias sociais produzem a fragmentação dos partidos, mas sugerimos que, em contexto de dissidência interna, é possível encontrar, nas mídias digitais, canais que oferecem visibilidade para as facções, o que não era possível nos meios de massa. Além disso, outros estudos podem enriquecer os achados com observações qualitativas e de caráter etnográfico sobre o uso das mídias digitais por partidos e facções para compreender como e por que elas publicizam as controvérsias e quais os impactos disso na formação de consensos e na coordenação interna. 


\section{Referências bibliográficas}

ACKLAND, R.; GIBSON, R. "Hyperlinks and networked communication: a comparative study of political parties online". International Journal of Social Research Methodology, vol. 16, no 3, p. 231-244, 2013.

Albuquerque, A. "Protecting democracy or conspiring against it? Media and politics in Latin America: a glimpse from Brazil". Journalism, vol. 20, no 7, p. 906-923, 2019.

Albuquerque, A.; Martins, A. F. "Apontamentos para um modelo de análise dos partidos na web". In: $19^{\circ}$ Encontro Anual da Compós, Rio de Janeiro, 2010.

Albuquerque, A.; Steibel, F. B.; CARneiro, C. M. Z. "A outra face do horário gratuito: partidos políticos e eleições proporcionais na televisão". Dados, vol. 51, no 2, p. 459-487, 2008.

AMARAL, O. M. "As transformações na organização interna do Partido dos Trabalhadores entre 1995 e 2009". Tese de doutorado em ciência política. Unicamp, Campinas, 2010.

ANSTEAD, N.; CHADWICK, A. Parties, election campaigning, and the internet toward a comparative institutional approach. In: CHADWICK, A.; HoWARD, P. (orgs.). The Routledge handbook of internet politics. London: Routledge, 2008.

BARBERÁ, P. "Birds of the same feather tweet together: bayesian ideal point estimation using Twitter data". Political Analysis, vol. 23, no 1, p. 76-91, 2015.

Bennett, W. L.; Segerberg, A. "The logic of connective action: digital media and the personalization of contentious politics". Information, Communication \& Society, vol. 15, no 5, p. 739-768, 2012.

BlANCHARD, G. "O uso da internet a serviço da comunicação do partido". Líbero, vol. 18, p. 9-17, 2016.

Blondel, V. D., et al. "Fast unfolding of communities in large networks". Journal of Statistical Mechanics: Theory and Experiment, vol. 10, 2008.

Braga, S.; FrançA, A.; NicolÁs, M. A. "Os partidos políticos brasileiros e a internet". Revista de Sociologia e Política, vol. 17, no 34, p. 183-208, 2009.

Braga, S.; Rocha, L. C.; Carlomagno, M. C. "A internet e os partidos políticos brasileiros". Cadernos Adenauer, vol. 16, no 3, p. 47-74, 2015.

Ceron, A. "Intra-party politics in 140 characters". Party Politics, vol. 23, no 1, p. 7-17, 2017.

CERVI, E. U. "O uso do HGPE como recurso partidário em eleições proporcionais no Brasil: um instrumento de análise de conteúdo". Opinião Pública, vol. 17, no 1, p. 106-136, 2011.

COLEMAN, S. "New mediation and direct representation: reconceptualizing representation in the digital age". New Media \& Society, vol. 7, no 2, p. 177-198, 2005.

DIAS, M. R. "Projeção da imagem partidária nas estratégias de campanha na televisão: uma análise do HGPE 2002". Dados, vol. 48, no 1, p. 149-187, 2005.

. "Nas brumas do HGPE: a imagem partidária nas campanhas presidenciais brasileiras (1989 a 2010)". Opinião Pública, vol. 19, nº 1, p. 198-219, 2013.

Dos SANTOS, R.; TRAVAgin, L. "As eleições para prefeito no Rio de Janeiro: uma análise sobre partidos, coligações e a política subnacional". Teoria \& Pesquisa, vol. 24, n 2, p. 121-143, 2015. 
DUVERGER, M. Os partidos políticos. Rio de Janeiro: Zahar, 1970.

ENLI, G. S.; SKogerb $\varnothing$, E. "Personalized campaigns in party-centred politics: Twitter and Facebook as arenas for political communication". Information, Communication \& Society, vol. 16, no 5, p. 757$774,2013$.

GibSON, R. K.; Rommele, A. "Political parties and professionalized campaigning". The Harvard International Journal of Press/Politics, vol. 6, no 3, p. 1-43, 2001.

GIBSON, R. K.; WARD, S. A. "Proposed methodology for studying the function and effectiveness of party and candidate websites". Social Science Computer Review, vol. 18, n 3, p. 301-319, 2000.

2009. . "Parties in the digital age - A review article". Representation, vol. 45, n 1, p. 87-100,

HSU, C. L.; PARK, H. W. "Sociology of hyperlink networks of Web 1.0, Web 2.0, and Twitter: a case study of South Korea". Social Science Computer Review, vol. 29, no 3, p. 354-368, 2011.

HUNTER, W. The transformation of the Workers' Party in Brazil. 1989-2009. Cambridge: Cambridge University Press, 2010.

JACKSON, N. A.; LILLEKER, D. G. "Building an architecture of participation? Political parties and Web 2.0 in Britain". Journal of Information Technology \& Politics, vol. 6, n 3-4, p. 232-250, 2009.

LEAL, O. R. F. PT e o dilema da representação política. Rio de Janeiro: FGV Editora, 2005.

LILleKER, D. G.; PACK, M.; JACKSON, N. "Political parties and Web 2.0: the liberal democrat perspective". Politics, vol. 30, n² 2, pp. 105-112, 2010.

MAOR, M. "Intra-party determinants of coalition bargaining". Journal of Theoretical Politics, vol. 7, no 1, p. 65-91, 1995.

MARGOLIS, M.; RESNICK, D.; TU, C. "Campaigning on the internet: parties and candidates on the world wide web in the 1996 primary season". Harvard International Journal of Press/Politics, vol. 2, n 1, p. $59-78,1997$.

MiChels, R. A lei de ferro da oligarquia. Rio de Janeiro: Zahar Editores, 1954.

MoRAIS, M. "A estrutura organizacional do Partido Socialismo e Liberdade (PSOL)". Anais do III Seminário de Pesquisa da Fapesp, São Paulo, 2014.

Mosco, V. The digital sublime: myth, power and cyberspace. Cambridge, MA: MIT Press, 2004.

NoRRIS, P. "Preaching to the converted? Pluralism, participation and party websites". Party Politics, vol. 9, no 1, p. 21-45, 2003.

PAneBIAnco, A. Modelos de partido: organização e poder nos partidos políticos. São Paulo: Martins Fontes, 2005.

PolK, J.; KolLn, A. K. "The lives of the party: contemporary approaches to the study of intraparty politics in Europe". Party Politics, vol. 23, n 1, p. 3-6, 2017.

ReCUeRo, R. Redes sociais na internet. Porto Alegre: Sulina, 2009.

RoCHA, L. C. "Os partidos na rede: ação política virtual das instituições partidárias brasileiras". Dissertação de mestrado em ciência política. Universidade Federal do Paraná, Curitiba, 2014. 
ROMmele, A. "Political parties, party communication and new information and communication technologies". Party Politics, vol. 9, no 1, p. 7-20, 2003.

Rose, R. "Parties, factions and tendencies in Britain". Political Studies, vol. 12, no 1, p. 33-46, 1964.

SANTOS, F.; GUARNIERI, F. "From protest to parliamentary coup: an overview of Brazil's recent history". Journal of Latin American Cultural Studies, vol. 25, no 4, p. 485-494, 2016.

Strommer-Galley, J. "Online interaction and why candidates avoid it". Journal of Communication, vol. 50 , no 4, p. 111-132, 2000.

Presidential campaigning in the internet age. Oxford: Oxford University Press, 2014.

SCHMITT, R.; CARNEIRO, L.; KUSCHNIR, K. "Estratégias de campanha no horário gratuito de propaganda eleitoral em eleições proporcionais". Dados, vol. 42, nº 2, p. 277-301, 1999.

SEARA, B. "PSOL versus PSOL". Jornal Extra, p. 8, 2016.

VACCARI, C. "Research note: Italian parties' websites in the 2006 elections". European Journal of Communication, vol. 23, no 1, 69-77, 2008.

WolinetZ, S. B. Beyond the catch-all party: approaches to the study of parties and party organization in contemporary democracies. In: GUNTHER, R.; MONTEIRO, J. R.; LINZ, J. (orgs.). Political parties: old concepts and new challenges. New York: Oxford University Press, p. 136-165, 2002.

\section{Abstract \\ PSOL versus PSOL: factions, parties and digital media}

This paper investigates the challenges posed by social media to the directive head of the parties to define the majority discourse. The hypothesis is that in a context of party fragmentation, social media offer opportunities for internal currents to vocalize dissatisfactions and to publicly negotiate their agendas publicly, which generates external noise and hinders consensus. The case study focuses on the coalition negotiations among PSOL factions, PT, PCdoB and Rede for the 2016 Rio de Janeiro City Hall election. This study has collected public data by querying the Facebook Graph API, searching fan pages of leaders, directories, factions and local representations. The sample is composed of 189 pages, from which 54 are connected to PSOL organization and 10 factions. The findings indicate the structural distance between the communicative subsystems organized around PSOL and PT / PCdoB, with separate clusters on Facebook and a strong public discussion about the composition of the electoral alliance.

Keywords: social media; party; PSOL; left; Facebook

\section{Resumen}

PSOL versus PSOL: facciones, partidos y medios digitales

Este artículo investiga los desafíos que presentan las redes sociales en relación con el poder de las cumbres de los partidos para definir el discurso mayoritario. La hipótesis es que en un contexto de fragmentación de los partidos, los medios de comunicación social ofrecen oportunidades para que las corrientes internas vocalicen las insatisfacciones y negocien sus programas públicamente, lo que genera ruido externo y dificulta el consenso. El estudio de caso se centra en las disputas entre las diferentes facciones de PSOL sobre la alianza con PT, PCdoB y las elecciones del Consejo de la Ciudad de Río de Janeiro en 2016. Recopilamos datos de solicitudes a Graph API para aumentar la presencia de líderes, directorios, facciones y núcleos de las cuatro partes, que comprenden una muestra de 189 páginas de admiradores, de las cuales 54 representan PSOL, de las cuales 10 facciones. Los resultados indican la distancia estructural entre los subsistemas comunicativos organizados en torno a PSOL y PT/PCdoB, con grupos separados en Facebook y una fuerte discusión pública sobre la composición de la alianza electoral. 
Palabras clave: redes sociales; partido; PSOL; izquierda; Facebook

\section{Résumé}

PSOL contre PSOL: factions, partis et communication numérique

Cet article examine les défis que les médias sociaux présentent pour le pouvoir des sommets de partis de définir le discours de la majorité. Sur la base de l'approche organisationnelle théorique de la communication entre partis, I'hypothèse est que les médias sociaux fragmentent la communication entre partis divisés et offrent aux courants internes la possibilité d'exprimer leur mécontentement et de négocier publiquement leurs programmes. L'étude de cas porte sur les différends entre différentes factions du PSOL sur l'alliance avec PT, PCdoB et les élections du conseil municipal de Rio de Janeiro en 2016. Nous avons collecté des données à partir de demandes adressées à Graph API afin de renforcer la présence de dirigeants, répertoires, factions et noyaux des quatre partis, comprenant un échantillon de 189 pages de fans, dont 54 représentent le PSOL, dont 10 factions. Les résultats indiquent la distance structurelle entre les sous-systèmes de communication organisés autour du PSOL et du PT / PCdoB, avec des clusters séparés sur Facebook et un débat public animé sur la composition de l'alliance électorale.

Mots clés: médias sociaux; parti; PSOL; gauche; Facebook

Artigo submetido à publicação em 25 de outubro de 2019. Versão final aprovada em 20 de março de 2020.

Opinião Pública adota a licença Creative Commons CC-BY. OPINIÄO PÜBLICA 